\title{
METHODOLOGY FOR DETERMINING INFLUENCE OF ORGANIZATIONAL CULTURE TO BUSINESS PERFORMANCE
}

\author{
E. Skoumalová, B. Minařík
}

Received: February 13, 2007

\begin{abstract}
SKOUMALOVÁ, E., MINAŘÍK, B.: Methodology for determining influence of organizational culture to business performance. Acta univ. agric. et silvic. Mendel. Brun., 2007, LV, No. 3, pp. 123-132

Content this article is to propose the possible methodology for quantitative measuring the organizational culture using the set of statistical methods. In view of aim we elected procedure consisting of two major sections. The first is classification of organizational culture and role of quantitative measurement on organizational culture. This part includes definition and several methods used to classify organizational culture: Hofstede, Peters and Waterman, Deal and Kennedy, Edgar Schein, Kotter and Heskett, Lukášová and opinions why a measurement perspective is worthwhile. The second major section contains methodology for measuring the organizational culture and its impact on organizational performance. We suggest using structural equation modeling for quantitative assessment of organizational culture.
\end{abstract}

organizational culture, statistical methods, structural equation modeling, organizational performance

Regarding present-day trends in development of the world's economy, all kinds of companies have to do everything to be competitive. It is necessary to find long-term competitive advantages, which is hardly imitable by another company. So not only low production costs or product quality is sufficient. Companies have to be healthful and strong inside to gain required organizational performance and that way achieve their strategic goals. In the last decades organizational performance has increasingly been linked to organizational culture, because of researchers has postulated that organizational culture plays a key role in organizational outcomes. Organizational culture has got straight impact on organizational performance and it can be long-term competitive advantage of company. Organizational culture originates as consequence of the certain managerial style. It is necessary to note that each company has got its own organizational culture.

The measurement of the organizational culture is significant and important for at least four reasons. First, it plays a key role in organizational outcomes.
Second it contributes to better understanding of company functioning. Third, it enables to identify which cultural component has got the greatest positive influence on organizational outcomes. Fourth, it enables to identify which cultural component has got negative influence on organizational outcomes. But scholars still disagree on the best way to measure it.

The goal of this article is to propose the possible methodology for quantitative measuring the organizational culture using the set of statistical methods.

\section{MATERIAL}

Despite increased research about importance of organizational culture, there is no consensus of options what does the term culture means. One well-known anthropological definition describes that culture is summary of thinking, feeling and reacting, transmitted by symbols (Kluckhohn, as cited in Hofstede, 2001, p. 9). Kroeber and Parsons study (as cited in 
Hofstede, 2001, p. 9) define culture as "transmitted and created content and patterns of values, ideas and other symbolic-meaningful systems as factors in the shaping of human behavior and the artifacts produced through behavior". Lukášová et al. (2004, p. 17) defines, that culture is abstract concept initiated by people to describe and understand similarity of individual intra-system and dissimilarity of intra-system. Content of culture, comprehensive of values, opinions, norms and cultural patterns, which determinate way of thinking, feeling, behavior and their products of tangible and intangible nature, is for each system specific and is transmitted from generation to generation by means of learning. Matsumoto (2000) defines culture as dynamic system of implicit and explicit rules created by group in order to survive, comprehensive of attitudes, values, opinions and norms of behavior. He further argues, that in fact we observe manifestation of the culture, no culture by itself.

Hofstede (2001, p. 9) claimed that culture is "the collective programming of the mind that distinguishes the members of one group or category of people from another". Word "mind" represents feeling, thinking and acting with implications on beliefs, attitudes and skills. Kluckhohn (as cited in Hofstede, 2001, p. 10) describes that culture include value, which is a core attribute of culture. Culture consists of invisible and visible elements (Hofstede, 2001). Values are invisible elements. Symbols, heroes and rituals are visible elements, which Hofstede (2001, p. 10) subsumes under the term practices. "A value is a conception, explicit or implicit, distinctive of an individual or characteristic of a group, of the desirable which influences the selection from available modes, means and ends of actions" (Hofstede, 2001, p. 5). Hofstede (2001, p. 10) notes that symbols are words, gestures, pictures and objects. Heroes are people who possess characteristics that are highly prized in a culture. Rituals are collective activities that are unnecessary to the achievement of desired goals. Cohen (as cited in Hofstede, 2001, p. 36) claimed that "symbols are objects, acts, relationship or linguistic formations that stand ambiguously for a multiplicity of meanings, evoke emotions, and impel people to action". Hofstede (2001, p. 10) notes, that culture could be defined as "the interactive aggregate of common characteristics that influence a human group's response to its environment".

Lukášová et al. (2004, p. 10) claimed, that culture is in each individual in appearance his or her opinions, values, attitudes and behavior patterns. Bloom (as cited in Hofstede, 2001, p. 36) claimed that development of values in children goes along with the development of intelligence and personality traits in the early years, from 2 to about 7 and these are firmly in place and unlikely to change even if that person migrates to another culture later.

"Organizations are symbolic entities; they function according to implicit models in the minds of their members, and these models are culturally determined" (Hofstede, 2001, p. 375). Organizational culture is not the same as national culture and it appears from national culture. Organizational cultures were the object of a separate study. Whereas national cultures differed primarily in their values, organizational cultures turned out to differ mainly in their practices (Hofstede, 2001, p. 373). Both culture and national culture are extremely stable over time.

Hofstede (2001, p. 391) defines organizational culture as "the collective programming of the mind that distinguishes the members of one organization from another". Professor Elliot Jaques (as cited in Hofstede, 2001, p. 393) claimed that "The culture of the factory is its customary an traditional way of thinking and of doing things, which is shared to a greater or lesser degree by all its member, and which new members must learn and at least partially accept..." Peters and Waterman (1993) noted that excellent companies are characterized by strong cultures and that shared values represent the core of such strong culture. They found that these organizations held values about quality, service and importance of people as individuals, and innovation that motivated employees to improve performance and increase their morale, satisfaction and commitment. Organizational culture determines norms of acceptable and unacceptable behavior, making it clear for employees what they should say or do (Kotter \& Heskett, 1992). Culture is allowed to be objective entity, certain aspect or subsystem of organization, one organization variable which influences functioning and performance of organization and it can be purposefully create and change (Lukášová et al. 2004, p. 21). Deal and Kennedy (1982) defines organizational culture as the way things get done around here. According to Edgar Schein (1992) organizational culture is illuminated from the standpoint of the speculator, described by three cognitive levels of organizational culture. The first level is termed artifacts. This most cursory level can be seen, felt and heard to the uninitiated speculator. The next level, which is termed values and norms, is partially conscious for external speculator, partially clear and partially suggestible. The third level, termed basic assumptions, is deepest unconscious level.

As noted earlier there is no consensus about definition of organizational culture but most authors agree with statement, that organizational culture comprises the attitudes, values, beliefs, norms and customs of an organization. This attributes are very difficult measurable. 
Researchers have postulated that organizational culture plays a key role in organizational outcomes. Common hypothesis about this role suggest, that if an organization possesses "strong culture" then it will perform at a higher level of productivity (Dennison as cited in Marcoulides \& Heck, 1993). Deal and Kennedy's study (as cited in Marcoulides \& Heck, 1993) postulates, that "the development of theory to guide the definition of organizational culture therefore is of primary importance to improving organizational performance, especially because the variables which comprise culture have been postulated to be under the control of organizational leaders".

Organizational culture is created by people in companies. As mentioned above the organizational culture is especially influenced by leaders and board of management of the companies. Hofstede (2001, p. 408) claimed that "the crucial element is not the organizational culture itself, but what (top) management does with it". Managerial functions are affected by their own values. Gulik (as cited in Pošváŕ, 2002, p. 10) describes that basic managerial functions are: planning, organizing, staffing, directing, coordinating, reporting and budgeting. It implies that they have got a strong influence over subordinates. Hofstede (2001, p. 381) claimed that "planning represents an attempt to reduce uncertainty; control implies the exercise of power......planning and control processes in organizations reflect basic cultural assumptions, and that they are related to the power distance and uncertainty avoidance norms of the dominant national culture. Planning and control systems are more than rational tools; they contain an element of ritual......they impose norms on organizations". Hofstede (2001, p. 382 ) further noted, that accounting systems and people who administer them play an important cultural role in organizations. As mentioned above, culture is manifested by symbols, heroes, rituals and values. And "accounting is said to be the language of business - this means that accounting is the handling of symbols..." Accounting systems have got an important role in identifying heroes in organizations, by reason that determine who is the good and bad employee.

Concerning developing successful mangers Hofstede (2001, p. 390) noted, that there is no "single formula" that can be used in various cultures, because especially system of basic education in schools and training on the job are very different.

Of what is above mentioned implies, that success of each organization consist in their culture and con- sequently it is very interesting for mangers to assess separate cultural attributes and their impact on organizational performance.

Measurement of organization's performance proposed by Hofstede is shown in Scheme 1. "Strategies are carried out via the existing structure and control system, and their outcome is modified by the organization's culture; and all these four elements influence each other" (Hofstede, 2001, p. 408). The link between strategy and culture means, that the two should fit, and if they do not, one of the two should be adapted. Adapting the strategy is usually simpler and cheaper than adapting the culture.

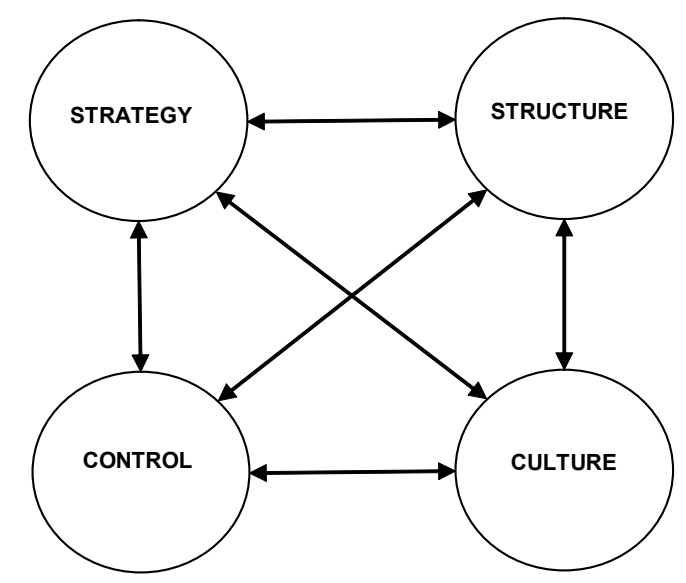

1: A Model for the Relationship among Strategy, Structure, Control, and Culture (based on Hofstede, 2001, p. 409)

The link between control and culture means, that culture is organic form of control of behavior. Hofstede further assumes that the most effective way of changing culture is through structural rearrangements, so it is necessary to include this variable into model. One area, where the link between strategy and culture is extremely important is problem with mergers and takeovers, because organization has to cope with traumatic culture shocks.

Morton (as cited in Pošvár̆, 2002) describes model of culture with impact on management. This model is shown in Scheme 2. Managerial processes are carried out via the strategy, structure, technology, people and their roles. Outcome of all these components is influenced by the organization's culture and all these attributes influence each other. 


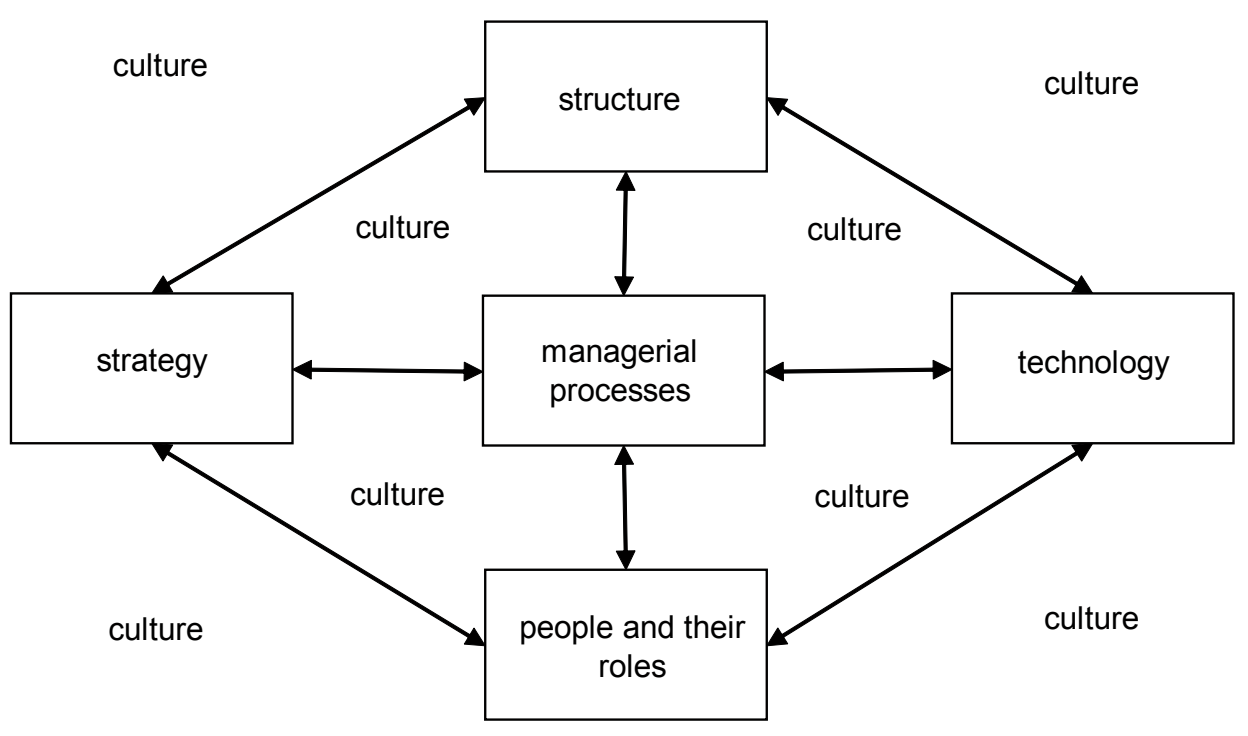

2: Components of management and their relations (Pošvář based on Morton, 2002, p. 50)

Another approach in successful organization described by Veber et al., (2003, p. 350) is shown in Scheme 3. Strategy, culture, structure and processes are internal factors. On the top is organization influ- enced by external factors. In contrast to model mentioned above where culture transmits through whole model, in this culture is one attribute of the model.

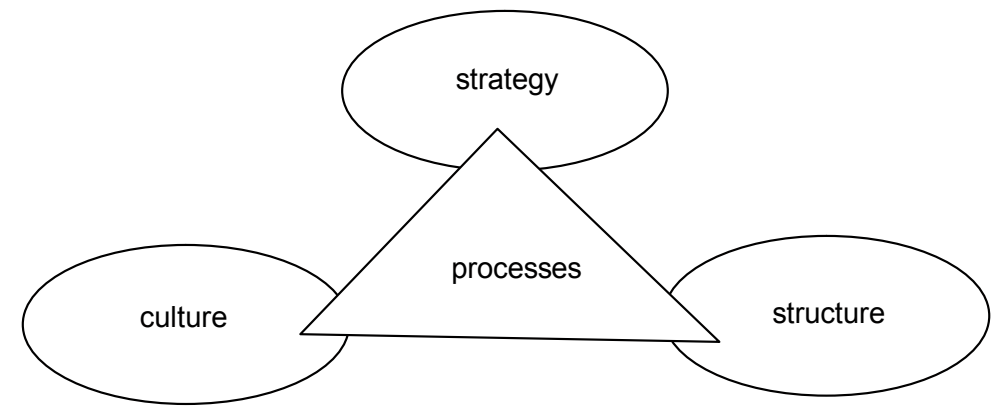

3: Factors of prosperity (based on Veber et al., 2003, p. 350)

Model "7S" by consultant firm McKinsey characterizes the most important factors which implicate a high organization performance (Peters \& Waterman, 1993). This model is shown in Scheme 4. Shared values are set in the middle of the model and represent the organizational culture.

Continuous improvement is a managerial model which assume, that change one of component evoke changes of the other components and in this way organization can achieve high performance. This model is shown in Scheme 5.

\section{METHODS}

All models mentioned above contain culture as one component of the organizational performance. Organizational culture consists of a hardly measurable attributes. Essential method how to measure organizational culture is a questioning. It is necessary to emphasize that it is subjective method in respect of both proposition of the questionnaire and informant answers. Lukášová et al. (2004, p. 104) claimed that critical phase of questionnaire construction is choice of cultural indicators; it means that culture is a very complicated phenomenon so it is not possible to involve all cultural aspects. 


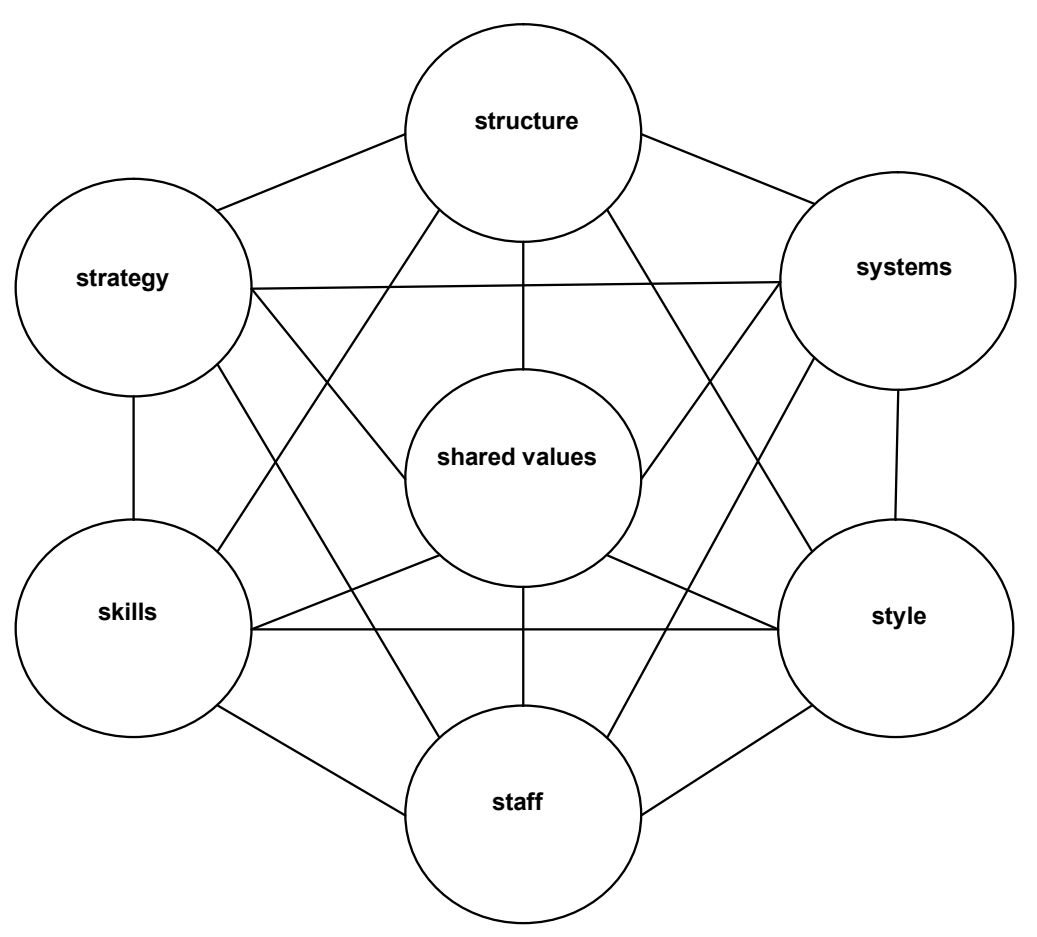

4: “7S" by McKinsey (based on Peters \& Waterman, 1993)

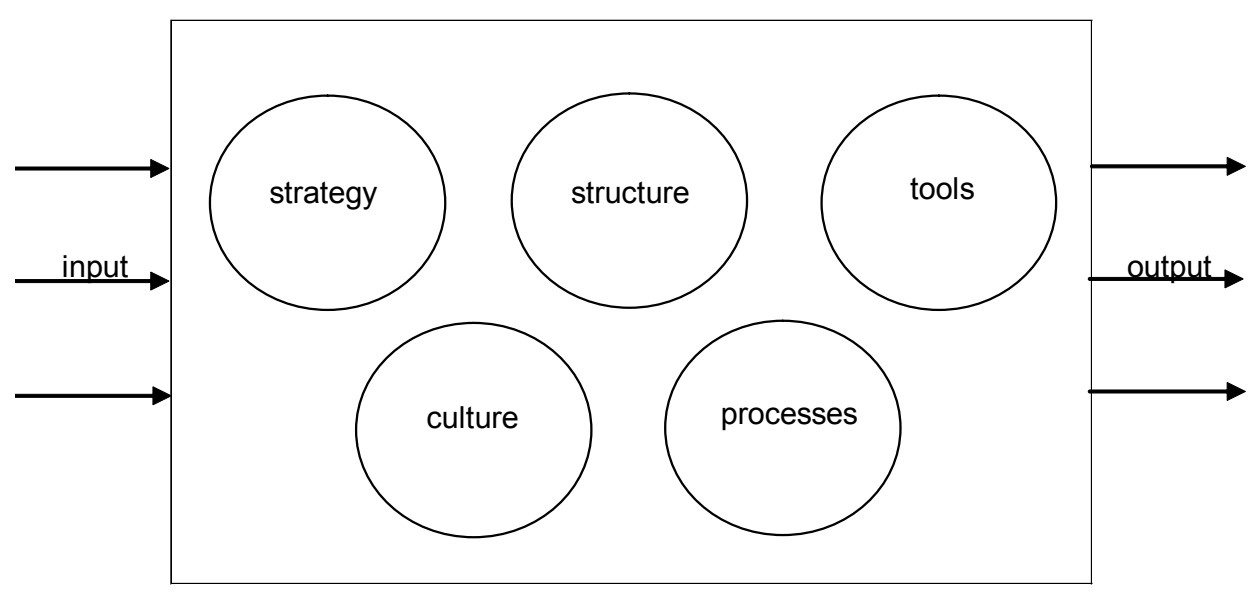

5: Continuous improvement (based on Pošváŕ, 2002, p. 84)

The purpose of this article is to propose model and methodology for measurement of the organizational culture and its impact on organizational performance. The method we have chosen is a structural equation modeling technique as measurement method.

Structural equation modeling is a statistical methodology that takes confirmatory approach to the multivariate analysis of a structural theory bearing on some phenomenon. It may be viewed as a guide that allows the researcher to assess the relative strength of each variable included in explaining a desired set of outcomes (Marcoulides \& Heck, 1993). The causal processes are represented by a series of structural equations or these structural relations can be demonstrated pictorially that allows a clearer understanding (Byrne, 1998, p. 3).

Structural equation modeling enables to analyze observed and unobserved variables. Unobserved (i.e. latent) variables or factors are those which cannot be observed directly, it follows, that they cannot be measured directly. Thus the latent variable has to be defined by "....behavior believed to repre- 
sent it. As such, the unobserved variable is linked to one that observable, thereby making its measurement possible"(Byrne, 1998, p. 4). Observed variables are termed manifest variables.

Structural equation modeling includes measurement model and structural model. Measurement model is based on factor analytic model, thus it focuses on the link between factors and their measured variable. "More specifically, it is concerned with the extent to which the observed variables are generated by the underlying latent constructs and thus strength of the regression paths from the factors to the observed variables..." (Byrne, 1998, p.6). In contrast to the measurement model, the structural model depicts the links among the latent variables themselves, it means that allows for the specification of regression structure among the latent variables.

This statistical model provides an efficient way of describing the latent structure underlying a set of observed variables. Expressed via a set of equations, this model explains how the observed and latent variables are related to one another. When the model is specified it is necessary to test its plausibility based on sample data that comprises all observed variables in the model. The primary task is to determine the goodness of fit between the hypothesized model and the sample data (Byrne, 1998, p. 7). Because it is highly unlikely that a perfect fit will exist between the observed data and the hypothesized model, there will be a discrepancy between the two; this discrepancy is termed the residual.

\section{RESULTS}

We suggest test the proposed model using LISREL program. One necessary requirement in working with LISREL is that researcher must distinguish between latent variables that are exogenous (i.e. independent) and those that are endogenous (i.e. dependent). Accordingly, the measurement model may be defined in terms of exogenous notation (i.e. X-variables) or in terms of endogenous notation (i.e. Y-variables). Each of these measurement models can be defined by one matrix and two vectors as follows: one regression matrix relating the exogenous $\left(\Lambda_{x}\right)$, or endogenous $\left(\Lambda_{y}\right)$ latent variables to their respective observed measures, one vector of latent exogenous $\left(\xi_{s}\right)$, or endogenous $\left(\eta_{s}\right)$ variables and one vector of measurement errors related to the exogenous $\left(\delta_{s}\right)$, or endogenous $\left(\varepsilon_{s}\right)$ observed variables. The structural model can be defined by two matrices and three vectors. These include one matrix of coefficients relating exogenous latent variables to endogenous latent variables $(\Gamma)$, one matrix of coefficients relating endogenous latent variables to other endogenous latent variables (B), one vector of latent exogenous variables $\left(\xi_{s}\right)$, one vector of latent endogenous variables $\left(\eta_{s}\right)$, and one vector of residual errors associated with the endogenous latent variables $(\zeta)$. Accordingly, the general LISREL model can be defined by the following three equations:

$$
\begin{aligned}
& x=\Lambda_{x} \xi+\delta \\
& y=\Lambda_{y} \eta+\varepsilon \\
& \eta=\mathrm{B} \eta+\Gamma \xi+\zeta
\end{aligned}
$$

As mentioned above the LISREL structural equation model can be demonstrated by the schematic pictorial presentation which is termed path diagram. Example of it with two latent variables and five observed variables is shown in Scheme 6. One-way arrows represent structural regression coefficients, i.e. indicate the impact of one variable to another.

Our proposal of the LISREL structural equation model is based on theoretical conception of organizational culture and managerial models, both mentioned above. Path diagram is presented schematically in Scheme 7. The outcome of interest is level of organizational performance. It is hypothesized that culture is composed of five interrelated latent variables, which together influence organizational performance. Organizational structure, organizational values and environment are exogenous latent variables. Organizational strategy, staff are endogenous latent variables. Each of these latent variables is defined in terms of observable variables. Description of the observable variables exceeds the scope of the present article.

Turning now to the measurement part of the model, in the concrete measurement model for the X-variables: the factors structure, values and environment are represented by $\xi_{1} ; \xi_{2} ; \xi_{3}$. The parameters $\lambda_{11} ; \lambda_{21} ; \lambda_{31}$ represent the regression of $X_{1} ; X_{2} ; X 3$ on $\xi_{1}$, and $\lambda_{42}$; $\lambda_{52} ; \lambda_{63}$ represent the regression of $X_{4} ; X_{5} ; X_{6}$ on $\xi_{2}$, and $\lambda_{73} ; \lambda_{83} ; \lambda_{93}$ represent the regression of $X_{7} ; X_{8} ; X_{9}$ on $\xi_{3}$. Finally, $\delta_{1}$ to $\delta_{9}$ represent errors of measurement associated with $X_{1}$ to $X_{9}$, respectively. Consistent with the model in Scheme 7 measurement model for the Xvariables can be summarized in terms of nine regression equations:

$$
\begin{aligned}
& x_{1}=\lambda_{11} \xi_{1}+\delta_{1} \\
& x_{2}=\lambda_{21} \xi_{1}+\delta_{2} \\
& x_{3}=\lambda_{31} \xi_{1}+\delta_{3} \\
& x_{4}=\lambda_{42} \xi_{2}+\delta_{4} \\
& x_{5}=\lambda_{52} \xi_{2}+\delta_{5} \\
& x_{6}=\lambda_{62} \xi_{2}+\delta_{6} \\
& x_{7}=\lambda_{73} \xi_{3}+\delta_{7} \\
& x_{8}=\lambda_{83} \xi_{3}+\delta_{8} \\
& x_{9}=\lambda_{93} \xi_{3}+\delta_{9}
\end{aligned}
$$




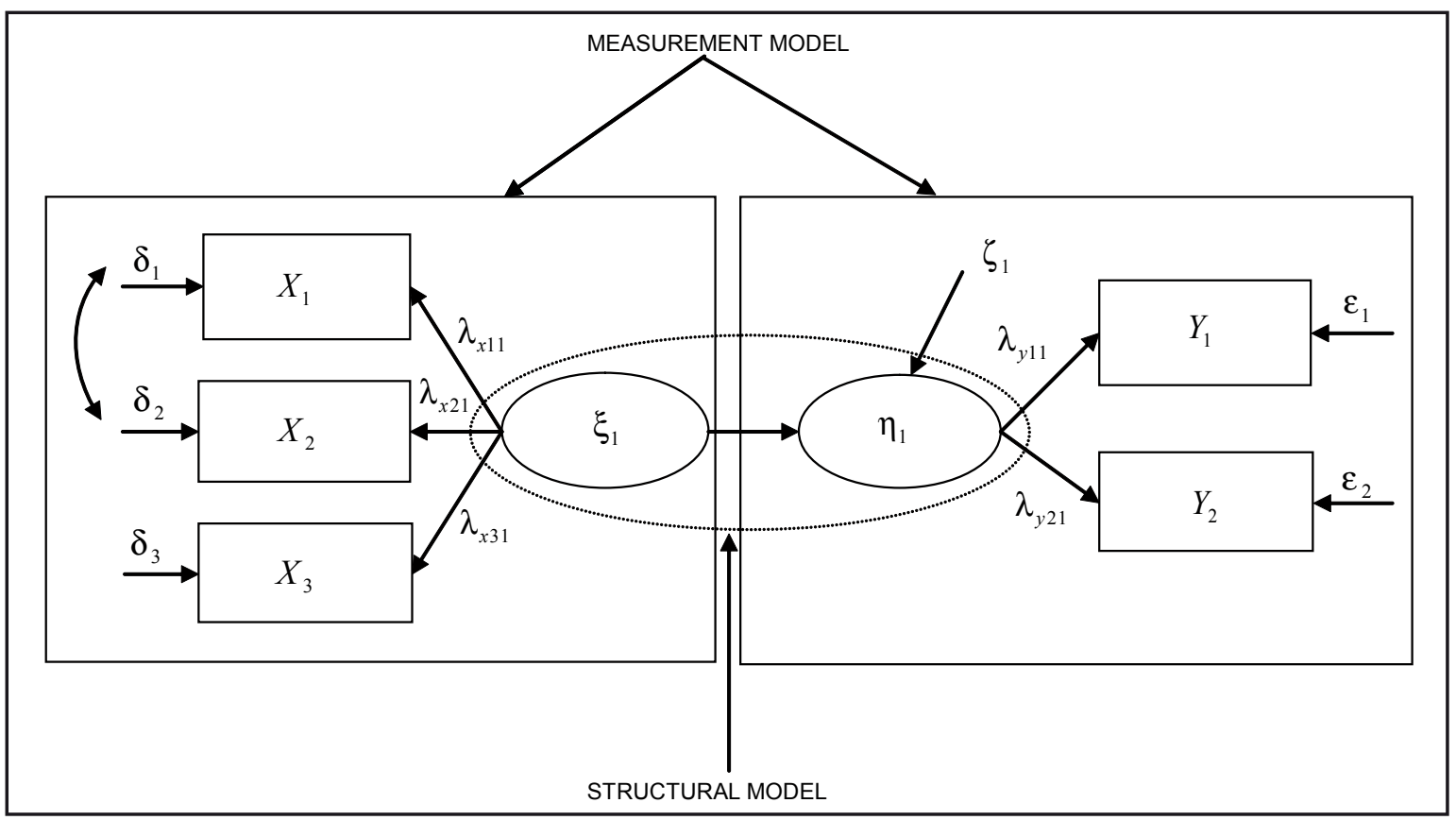

6: A LISREL Structural Equation Model (based on Byrne, 1998, p. 19)

This set of equations can be captured in matrix format as follows:

$$
\left[\begin{array}{l}
x_{1} \\
x_{2} \\
x_{3} \\
x_{4} \\
x_{5} \\
x_{6} \\
x_{7} \\
x_{8} \\
x_{9}
\end{array}\right]=\left[\begin{array}{lll}
\lambda_{11} & 0 & 0 \\
\lambda_{21} & 0 & 0 \\
\lambda_{31} & 0 & 0 \\
0 & \lambda_{42} & 0 \\
0 & \lambda_{52} & 0 \\
0 & \lambda_{62} & 0 \\
0 & 0 & \lambda_{73} \\
0 & 0 & \lambda_{83} \\
0 & 0 & \lambda_{93}
\end{array}\right]\left[\begin{array}{l}
\xi_{1} \\
\xi_{2} \\
\xi_{3}
\end{array}\right]+\left[\begin{array}{l}
\delta_{1} \\
\delta_{2} \\
\delta_{3} \\
\delta_{4} \\
\delta_{5} \\
\delta_{6} \\
\delta_{7} \\
\delta_{8} \\
\delta_{9}
\end{array}\right]
$$

The zeros are fixed values indicating that, for example $X_{1}$ and $X_{2}$ are specified to load on Factor 1 and not on Factor 2. In addition to the regression coefficients, the core parameters in any structural equation model also include the variances and covariance of the independent variables. So it is necessary to estimate it for all three factors as well as for the measurement errors. The regression equations for the Y-variables, consistent with the model in Scheme 7, are presented in Equation 4. The factors of measurement model for the Y-variables are presented by strategy $\left(\eta_{1}\right), \operatorname{staff}\left(\eta_{2}\right)$ and organizational performance $\left(\eta_{3}\right)$. The parameters $\lambda_{11}$ to $\lambda_{10,3}$ represent the regression of $Y_{1}$ to $Y_{10}$ on $\eta_{1}$ to $\eta_{3}$, respectively. Finally, $\varepsilon_{1}$ to $\varepsilon_{10}$ represent errors of measurement associated with $Y_{1}$ to $Y_{10}$, respectively.
Consistent with the model in Scheme 7 and regression equations in Equation 4, measurement model for the Y-variables can be captured in matrix format which is illustrated in Equation 5.

$y_{1}=\lambda_{11} \eta_{1}+\varepsilon_{1}$

$y_{2}=\lambda_{21} \eta_{1}+\varepsilon_{2}$

$y_{3}=\lambda_{31} \eta_{1}+\varepsilon_{3}$

$y_{4}=\lambda_{42} \eta_{2}+\varepsilon_{4}$

$y_{5}=\lambda_{52} \eta_{2}+\varepsilon_{5}$

$y_{6}=\lambda_{62} \eta_{2}+\varepsilon_{6}$

$y_{7}=\lambda_{73} \eta_{3}+\varepsilon_{7}$

$y_{8}=\lambda_{83} \eta_{3}+\varepsilon_{8}$

$y_{9}=\lambda_{93} \eta_{3}+\varepsilon_{9}$

$y_{10}=\lambda_{10,3} \eta_{3}+\varepsilon_{10}$ 


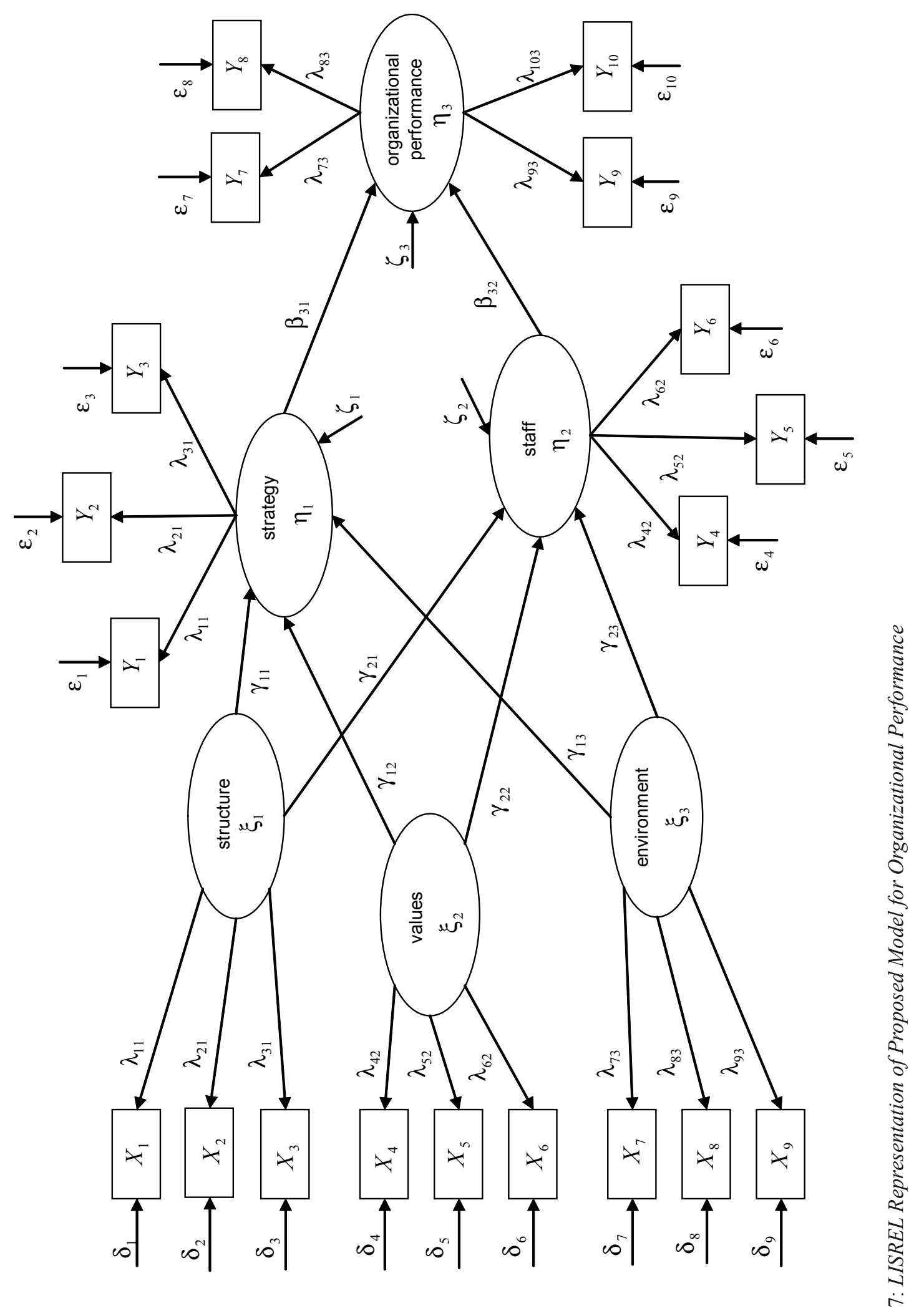




$$
\left[\begin{array}{l}
y_{1} \\
y_{2} \\
y_{3} \\
y_{4} \\
y_{5} \\
y_{6} \\
y_{7} \\
y_{8} \\
y_{9} \\
y_{10}
\end{array}\right]=\left[\begin{array}{lll}
\lambda_{11} & 0 & 0 \\
\lambda_{21} & 0 & 0 \\
\lambda_{31} & 0 & 0 \\
0 & \lambda_{42} & 0 \\
0 & \lambda_{52} & 0 \\
0 & \lambda_{62} & 0 \\
0 & 0 & \lambda_{73} \\
0 & 0 & \lambda_{83} \\
0 & 0 & \lambda_{93} \\
0 & 0 & \lambda_{10,3}
\end{array}\right]\left[\begin{array}{l}
\eta_{1} \\
\eta_{2} \\
\eta_{3}
\end{array}\right]+\left[\begin{array}{c}
\varepsilon_{1} \\
\varepsilon_{2} \\
\varepsilon_{3} \\
\varepsilon_{4} \\
\varepsilon_{5} \\
\varepsilon_{6} \\
\varepsilon_{7} \\
\varepsilon_{8} \\
\varepsilon_{9} \\
\varepsilon_{10}
\end{array}\right]
$$

The structural part of the model shown in Scheme 7 represents the hypothesis that organizational performance derives from strategy and staff, which are influenced by the structure, values and environment. Residual errors associated with the regression of $\eta_{s}$ on $\xi_{p}$ are captured by the disturbance terms $\zeta_{s}$. The set of equations for structural model are illustrated in Equations 6.

$$
\begin{aligned}
& \eta_{1}=\gamma_{11} \xi_{1}+\gamma_{12} \xi_{2}+\gamma_{13} \xi_{3}+\zeta_{1} \\
& \eta_{2}=\gamma_{21} \xi_{1}+\gamma_{22} \xi_{2}+\gamma_{23} \xi_{3}+\zeta_{2} \\
& \eta_{3}=\beta_{31} \eta_{1}+\beta_{32} \eta_{2}+\zeta_{3}
\end{aligned}
$$

\section{DISCUSSION AND CONCLUSION}

In this article we proposed theoretical structural equation model relating to organizational culture and its influence on organizational performance. Organizational culture is expressed by several latent variables: structure, values, strategy, environment and staff. These variables are hypothesized to effect orga- nizational performance. Structural equation modeling allows examine direct and indirect relationship between latent and observed variables and between latent variables each other. This study does not contain solving the questions of statistical identification and description of measurable variables.

We found out that similar study was made by Marcoulides and Heck, who proposed and tested model shown in Scheme 8. The coefficient of determination attained value 0.84 which indicates a relatively strong relationship between the observed and the latent variables included in their model. The result of their analysis indicate that all the latent variables have effect on the level of organizational performance observed with the largest direct effects being from worker attitudes $(0.93)$ and the task organization activities (0.71). Relatively large direct effects were noted between organizational values and organizational climate $(0.88)$ and between values and employee attitudes (0.78) (Marcoulides \& Heck, 1993).

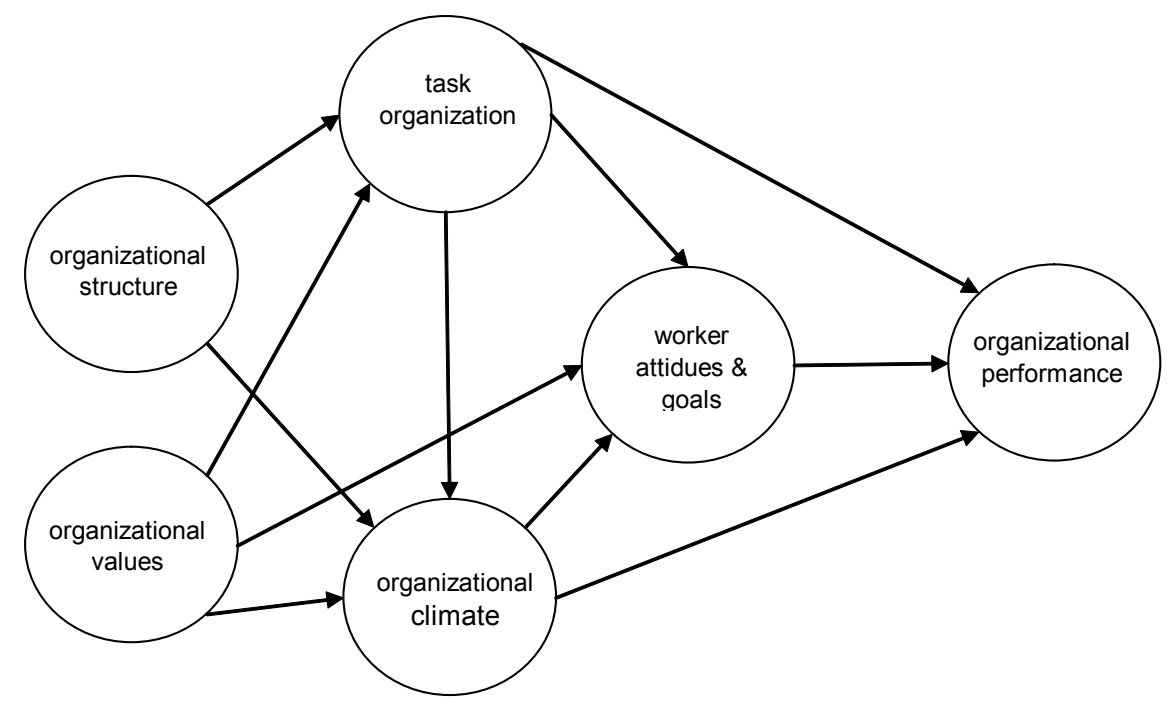

8: Model of variables influencing organizational performance (based on Marcoulides \& Heck, 1993) 
Structural equation modeling is a multivariate statistical technique used to examine direct relationships between one or more independent variables and one or more dependent variables. Structural equation modeling have been widely applied to many phenomena including macroeconomic policy formation, evaluation of social action programs, consumer behavior, intergenerational occupational mobility, racial discrimination in employment, voting behavior, scholastic achievement, and studies of genetic and cultu- ral effect. The leading program for structural equation modeling is LISREL.

It necessary to note, that somebody else could use another latent variables in proposed model. This question results from fact, that there is no uniform definition of organization culture. We are convinced that measurement of the organizational culture is significant and important for managers in organizations, who through visible and invisible elements of organizational culture can influence organizational performance.

\section{SOUHRN}

Metodologie pro určení vlivu organizační kultury na výkonnost organizace

Cílem tohoto příspěvku je návrh metodologie pro kvantifikaci vlivu organizační kultury na výkonnost organizace, s využitím statistických metod. Článek se skládá ze dvou hlavních částí. První část obsahuje definice organizační kultury a analyzuje důležitost kvantifikace vlivu organizační kultury na výkonnost. V druhé hlavní části je navržen strukturální model, pomocí něhož lze kvantifikovat vliv jednotlivých atributů organizační kultury na výkonnost organizace.

organizační kultura, statistické metody, strukturální modelování, organizační výkonnost

\section{REFERENCES}

BYRNE, B. M.: Structural equation modeling with LISREL, PRELIS, and SIMPLIS: Basic Concepts, Applications, and Programming. New Jersey. Lawrence Erlbaum Associates, Inc., Publishers, 1998.

DEAL, T. E. \& KENNEDY, A. A.: Corporate Cultures. Reading. Addison-Wesley Publishing Company, 1982.

HOFSTEDE, G.: Culture consequences: Comparing values, behaviors, institutions, and organizations across nations. Thousand Oaks. Sage Publications Inc., 2001. ISBN 0-8039-7324-1

KOTTER, J. P. \& HESKETT, J. L.: Corporate culture and performance. New York. Maxwell Macmillan, 1992.

LUKÁŠOVÁ, R., NOVÝ, I., et al.: Organizační kultura. Od sdilených hodnot a cílů $k$ vyšši výkonnosti podniku. Praha. Grada Publishing, a.s., 2004.

MARCOULIDES, G. A. \& HECK, R. H.: Organi- zational culture and performance: proposing and testing a model. Organization Science. 1993, 4(2), 209-255.

MATSUMOTO, D.: Culture and Psychology. Belmont. Wadsworth-Thomson Learning, 2000.

PETERS, T. J. \& WATERMAN, R. H.: Hledání dokonalosti. Praha. Svoboda-Libertas, 1993.

PORTER, M. E.: Konkurenční výhoda. Praha. Victoria Publishing, 1995.

PORTER, M. E.: The competitive advantage of nations. Harvard Business Review, 1990, 68(4), 73-93.

POŠVÁŘ, Z. \& ERBES, J.: Management I. Brno. Mendelova zemědělská a lesnická univerzita v Brně, 2002.

SCHEIN, E.: Organizational culture and leadership. San Francisco. Jossey Bass Publishers, 1992.

URBÁNEK, T.: Strukturální modelování v psychologii. Brno. Psychologický ústav AV ČR v Nakladatelství - Pavel Křepela, 2000.

VEBER, J., at al.: Management. Základy, prosperita, globalizace. Praha. Management Press, 2003.

Address

Ing. Eva Skoumalová, Prof. Ing. Bohumil Minařík, CSc., Ústav statistiky a operačního výzkumu, Mendelova zemědělská a lesnická univerzita v Brně, Zemědělská 1, 61300 Brno, Česká republika, minarik@mendelu.cz, xskoumal@node.mendelu.cz 